\title{
Perbandingan Estimasi Metode Kuadrat Terkecil Terboboti dan Metode Transformasi Box-Cox Pada Data Heteroskedastisitas
}

\author{
Risma $^{1 *}$, Sitti Sahriman ${ }^{2}$, Sri Astuti Thamrin ${ }^{3}$ \\ 1,2,3 Departemen Statistika, Fakultas MIPA, \\ Universitas Hasanuddin, Makassar, 90245, Indonesia \\ * Corresponding author, email: rismahwan@gmail.com
}

\begin{abstract}
In estimating regression parameters generally used the least squares method. This method has several assumptions that need to be fulfilled, one of which is homoscedasticity. Violation of the homoscedasticity assumption can lead to inefficient estimation models. Therefore, if there is a violation of homoscedasticity, the least squares method can no longer be used, so an alternative method is needed. Two methods to overcome homoscedaticity violations are weighted least squares method and Box-Cox transformation method. In this study, the weighted least squares method and the Box-Cox transformation method will be compared. From the application of the two methods, it is obtained that the least squared method has a smaller RMSE (root mean square error) and 22 which is greater than the Box-Cox transformation method. It can be concluded that the weighted least squares method is best used in dealing with homoscedasticity violations.
\end{abstract}

Keywords: Box-Cox Transformation, Heteroscedasticity, Weighted Least Square.

\begin{abstract}
Abstrak
Dalam mengestimasikan parameter regresi umumnya digunakan metode kuadrat terkecil. Metode ini memiliki beberapa asumsi yang perlu dipenuhi salah satunya yakni homoskedastisitas. Pelanggaran asumsi homoskedastisitas dapat menyebabkan model estimasi tidak efisien. Oleh karena itu jika terjadi pelanggaran homoskedastisitas maka metode kuadrat terkecil tidak dapat lagi digunakan,sehingga diperukan metode alternative. Metode untuk mengatasi pelanggaran homoskedatisitas dua diantaranya yakni metode kuadrat terkecil terboboti dan metode transformasi Box-Cox. Dalam penelitian ini akan dibandingkan metode kuadrat terkecil terboboti dan metode transformasi Box-Cox. Dari penerapan kedua metode tersebut didapatkan metode kuadrat terkecil terboboti memiliki RMSE (root mean square error) yang lebih kecil dan $\mathrm{R}^{2}$ yang lebih besar dibandingkan metode transformasi Box-Cox. Maka dapat disimpulkan metode kuadrat terkecil terboboti lebih bagus digunakan dalam menangani pelanggaran homoskedastisitas.
\end{abstract}

Kata Kunci: Heteroskedastisitas, Kuadrat Terkecil Terboboti, Transformasi Box-Cox.

\section{Pendahuluan}

Regresi merupakan teknik statistik untuk menentukan hubungan linear antara dua atau lebih variabel [1]. Model regresi linear dapat diperoleh dengan menaksir parameternya menggunakan metode kuadrat terkecil. Agar memenuhi sifat BLUE (best linear unbiased estimator) terdapat beberapa asumsi yang perlu dipenuhi dalam metode kuadrat terkecil diantaranya yakni berdistribusi normal, homoskedastisitas, tidak ada autokorelasi, dan tidak ada multikolinearitas. Jika terdapat asumsi yang dilanggar maka

Estimasi: Journal of Statistics and Its Application

e-ISSN: 2721-3803, p-ISSN: 2721-379X

http://journal.unhas.ac.id/index.php/ESTIMASI 
sifat BLUE (best linear unbiased estimator) tidak terpenuhi sehingga model yang diperoleh menjadi tidak efisien dan tidak dapat dipercaya [2].

Pelanggaran terhadap asumsi homoskedatisitas disebut heteroskedastisitas yakni keadaan dimana bahwa varian dari eror bersifat konstan [3]. Asumsi ini menyatakan variabel respon memiliki varian yang sama sepanjang nilai variabel prediktor. Jika terjadi heteroskedastisitas pada model regresi maka estimator yang diperoleh menjadi tidak efisien dikarenakan variansi tidak konstan dan cenderung membesar mengakibatkan uji hipotesis menjadi tidak valid,[4] sehingga jika tetap digunakan pada model regresi dapat mengakibatkan penaksir terlalu besar atau terlalu rendah. Jika dalam menaksir parameter dengan menggunakan metode kuadrat terkecil dan terjadi pelanggaran asumsi homokedastisitas yang berarti sifat BLUE (best linear unbiased estimator) tidak terpenuhi, maka diperlukan suatu metode alternatif untuk mengatasi adanya heteroskedastisitas [3].

Salah satu metode yang dapat digunakan dalam mengatasi pelanggaran asumsi homoskedastisitas diantaranya yakni metode kuadarat terkecil terboboti dan metode transformasi Box-Cox. Metode kuadrat terkecil terboboti sebelumnya telah dikerjakan [4]. Metode kuadrat terkecil terboboti adalah metode yang menggunakan weight atau pembobot yang proporsional terhadap inverse (kebalikan) dari varians variabel respon [3] yang memiliki kemampuan untuk menetralisir akibat dari pelanggaran asumsi heteroskedastisitas dan dapat menghilangkan sifat ketidakbiasan dan konsistensi dari model taksiran metode kuadrat tekecil [4]. Metode kuadrat terkecil adalah metode yang bertujuan untuk meminimumkan jumlah kuadrat eror [5]. Adapun transformasi BoxCox merupakan transformasi pangkat pada variabel respon yang dikembangkan oleh Box dan Cox, yang bertujuan untuk menormalkan data, melinearkan model regresi dan menghomogenkan variansi [5].

Berdasarkan dari kedua penelitian dengan metode yang berbeda penulis ingin mengetahui cara pengaplikasian metode kuadrat terkecil terboboti dan metode transformasi Box-Cox serta mengetahui metode manakah yang terbaik digunakan dalam mengatasi heteroskedastisitas pada data banyaknya usaha/perusahaan, pendapatan, dan pengeluaran usaha mikro kecil menurut wilayah di Indonesia tahun 2016.

\section{Material dan Metode}

Data yang digunakan pada penelitian ini adalah data sekunder, yakni data banyaknya usaha/perusahaan, pendapatan, dan pengeluaran usaha mikro kecil menurut wilayah dengan total 34 Provinsi di Indonesia tahun 2016. Variabel dalam penelitian ini terdiri dari 1 variabel respon, 2 variabel prediktor dan 1 variabel dummy. Variabel pendapatan sebagai variabel respon $(\mathrm{Y})$, Banyak usaha sebagai variabel prediktor $\left(\mathrm{X}_{1}\right)$, Variabel pengeluaran sebagai $\left(\mathrm{X}_{2}\right)$, dan variabel pendapatan diklusterkan kemudian dijadikan sebagai dummy $\left(\mathrm{D}_{1}\right)$. 
Heteroskedastisitas yakni kasus dengan asumsi homokedastisitas dilanggar, yang artinya eror bersifat tidak konstan. Konsekuensi dari terjadi heteroskedastisitas dapat mengakibatkan penduga metode kuadrat terkecil yang diperoleh tetap memenuhi persyaratan tak bias, tetapi varian yang diperoleh menjadi tidak efisien, artinya varian cenderung membesar sehingga tidak lagi merupakan varian yang kecil. Dengan demikian model perlu diperbaiki terlebih dahulu, agar pengaruh dari heteroskedastisitas hilang [6] salah satu metode yang dapat digunakan untuk mengatai hal ini adalah metode kuadrat terkecil terboboti dan metode transformasi Box-Cox.

\subsection{Metode Kuadrat Terkecil Terboboti}

Menurut Montogometry untuk mengatasi model regresi dengan varian eror tidak konstan dapat dilakukan dengan metode kuadrat terkecil terboboti. Metode ini memiliki kemampuan untuk mempertahankan sifat efisiensi estimatornya tanpa harus kehilangan sifat tak bias dan konsistensinya [4]. Metode kuadrat terkecil terboboti pada prinsipnya sama dengan metode kuadrat terkecil, bedanya pada metode kuadrat terkecil terboboti terdapat penambahan variabel baru yaitu $\mathrm{W}$ yang menunjukkan bobot [3]. Estimasi parameter $\beta_{0} \beta_{1} \beta_{2}, \ldots, \beta_{k}$ untuk regresi linear berganda dengan metode kuadrat terkecil terboboti dapat dilihat sebagai berikut.

$$
\widehat{\boldsymbol{\beta}}=\left(\boldsymbol{W} \boldsymbol{X}^{\prime} \boldsymbol{X}\right)^{-1} \boldsymbol{W} \boldsymbol{X}^{\prime} \boldsymbol{Y},
$$

dengan matriks $\boldsymbol{W}$ merupakan matriks diagonal yang berisi pembobot $W_{n}$.

$$
\boldsymbol{W}=\left[\begin{array}{cccc}
W_{1} & 0 & \cdots & 0 \\
0 & W_{2} & \cdots & 0 \\
\vdots & \vdots & \ddots & \vdots \\
0 & 0 & \cdots & W_{n}
\end{array}\right]
$$

Pembobot $W_{n}$ dapat ditenntukan dengan melihat pola yang ditunjukkan sisaan (residual) terhadap variabel prediktor. Pola tersebut antara lain;

1. Varians eror proporsional terhadap $X_{i j}{ }^{2}$ untuk suatu $j$ dengan $1 \leq j \leq k$

$$
E\left(\varepsilon_{i}^{2}\right)=\sigma^{2} X_{i j}^{2}
$$

Jika dalam pendeteksian heteroskedastisitas menggunakan metode grafik diyakini bahwa varians eror proporsional terhadap nilai kuadrat dari variabel $X_{i j}$ seperti pada Gambar 1 berikut:

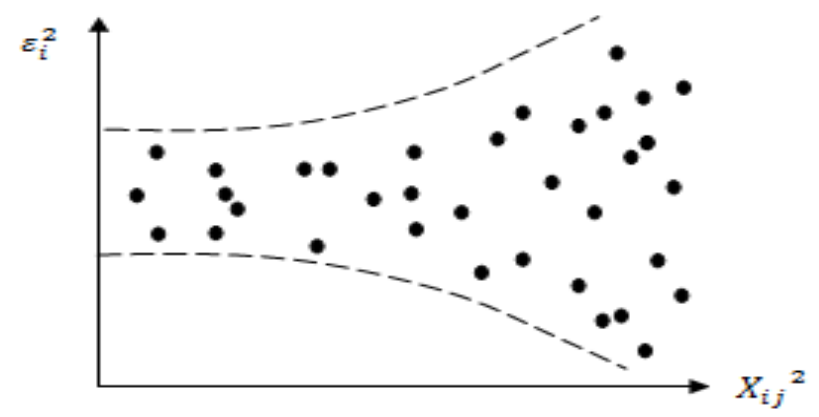

Gambar 1. Varians eror proporsional terhadap $\boldsymbol{X}_{i j}{ }^{2}$ 
Jika pola menunjukkan hubungan kuadrat seperti pada Gambar 1 maka dapat diasumsikan variansi eror proporsional terhadap $X_{i j}{ }^{2}$, sehingga pembobot yang digunakan dalam metode kuadrat terkecil terboboti adalah $\frac{1}{X_{i j}}$ sehingga persamaan regresinya menjadi.

$$
\begin{aligned}
\frac{Y_{i}}{X_{i j}} & =\frac{\left(\beta_{0}+\beta_{1} x_{i 1}+\beta_{2} x_{i 2}+\cdots+\beta_{j} x_{i j}+\cdots+\beta_{k} x_{i k}+\varepsilon_{i}\right)}{X_{i j}} \\
\frac{Y_{i}}{X_{i j}} & =\frac{\beta_{0}}{X_{i j}}+\beta_{1} \frac{X_{i 1}}{X_{i j}}+\beta_{2} \frac{X_{i 2}}{X_{i j}}+\cdots+\beta_{k} \frac{X_{i k}}{X_{i j}}+u_{i},
\end{aligned}
$$

dengan $\frac{\varepsilon_{i}}{X_{i j}}=u_{i}$ merupakan faktor eror yang telah ditransformasikan.

2. Varians eror proporsional terhadap $X_{i j}$

$$
E\left(\varepsilon_{i}^{2}\right)=\sigma^{2} X_{i j}
$$

Jika dalam pendeteksian menggunakan metode grafik diyakini bahwa varians eror proporsional terhadap $X_{i j}$, seperti pada Gambar 2 berikut.

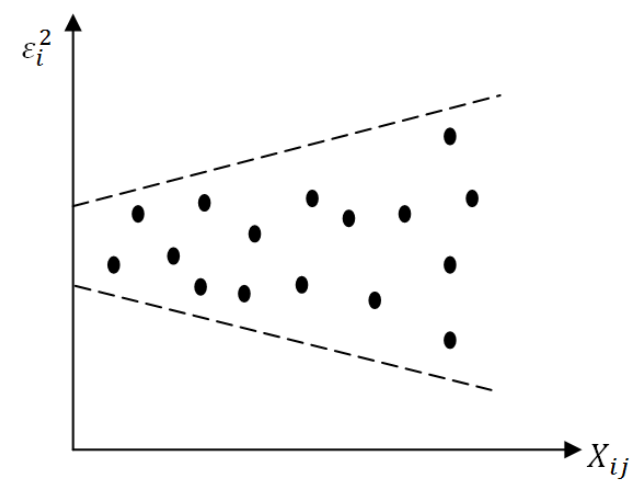

Gambar 2. Varians eror proporsional terhadap $\boldsymbol{X}_{\boldsymbol{i} \boldsymbol{j}}$

Jika pola menunjukkan hubungan linier seperti pada Gambar 2 maka dapat diasumsikan varians eror proporsional terhadap $X_{i j}$ sehingga pembobot yang digunakan adalah $\frac{1}{\sqrt{x i j}}$ sehingga persamaan regresinya menjadi.

$$
\begin{aligned}
& \frac{Y_{i}}{\sqrt{X_{i j}}}=\frac{\left(\beta_{0}+\beta_{1} x_{i 1}+\beta_{2} x_{i 2}+\cdots+\beta_{j} x_{i j}+\cdots+\beta_{k} x_{i k}+\varepsilon_{i}\right.}{\sqrt{X_{i j}}} \\
& \frac{Y_{i}}{\sqrt{X_{i j}}}=\frac{\beta_{0}}{\sqrt{X_{i j}}}+\beta_{1} \frac{X_{i 1}}{\sqrt{X_{i j}}}+\beta_{2} \frac{X_{i 2}}{\sqrt{X_{i j}}}+\cdots+\beta_{k} \frac{X_{i k}}{\sqrt{X_{i j}}}+u_{i},
\end{aligned}
$$

dengan $\frac{\varepsilon_{i}}{\sqrt{X_{i j}}}=u_{i}$, merupakan faktor eror yang telah ditransformasikan.

3. Varians eror proporsional terhadap $\left[E\left(Y_{i}\right)\right]^{2}$

$$
E\left(\varepsilon^{2}\right)=\sigma^{2}\left[E\left(Y_{i}\right)\right]^{2}
$$

Varians eror proporsional terhadap $\left[E\left(Y_{i}\right)\right]^{2}$, seperti diilustrasikan pada Gambar 3 berikut : 


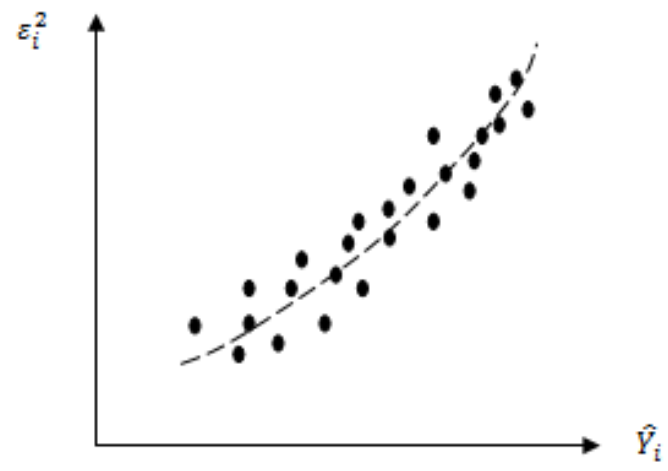

Gambar 2. Error kuadrat proporsional terhadap $\widehat{\boldsymbol{Y}}_{\boldsymbol{\iota}}$

Jika varians eror proporsional terhadap $\left[E\left(Y_{i}\right)\right]^{2}$,maka metode kuadrat terkecil terboboti dilakukan dengan meregresikan metode kuadrat terkecil dengan mengabaikan heteroskedastisitas untuk mendapatkan nilai $\widehat{Y}_{l}$ yang akan digunakan sebagai pembobot sehingga persamaan regresinya menjadi seperti berikut.

$$
\begin{aligned}
\frac{Y_{i}}{E\left(Y_{i}\right)} & =\frac{\left(\beta_{0}+\beta_{1} x_{i 1}+\beta_{2} x_{i 2}+\cdots+\beta_{j} x_{i j}+\cdots+\beta_{k} x_{i k}+\varepsilon_{i}\right.}{E\left(Y_{i}\right)} \\
\frac{Y_{i}}{E\left(Y_{i}\right)} & =\frac{\beta_{0}}{E\left(Y_{i}\right)}+\beta_{1} \frac{X_{i 1}}{E\left(Y_{i}\right)}+\beta_{2} \frac{X_{i 2}}{E\left(Y_{i}\right)}+\cdots+\beta_{k} \frac{X_{i k}}{E\left(Y_{i}\right)}+u_{i}
\end{aligned}
$$

dengan $\frac{\varepsilon_{i}}{E\left(Y_{i}\right)}=u_{i}$, merupakan faktor eror yang telah ditransformasikan. Nilai $\mathrm{E}\left(\mathrm{Y}_{\mathrm{i}}\right)$ bergantung pada besarnya $\beta_{0}$ dan $\beta_{1}$, sehingga transformasi persamaan (7) tidak dapat dioperasikan. Oleh karena itu digunakan estimator dari $Y_{i}$ yakni $\widehat{Y}_{i}$, sehingga perlu dilakukan regresi dengan metode kuadrat terkecil terlebih dahulu dengan mengabaikan heteroskedastisitasnya untuk mendapatkan nilai $\widehat{Y}_{i}$. Kemudian dari $\widehat{Y}_{i}$ yang telah didapatkan digunakan untuk mentransformasi Persamaan (7) menjadi sebagai berikut [3].

$$
\begin{aligned}
& \frac{\mathrm{Y}_{\mathrm{i}}}{\widehat{\mathrm{Y}}_{\mathrm{i}}}=\frac{\left(\beta_{0}+\beta_{1} \mathrm{x}_{\mathrm{i} 1}+\beta_{2} \mathrm{x}_{\mathrm{i} 2}+\cdots+\beta_{\mathrm{j}} \mathrm{x}_{\mathrm{ij}}+\cdots+\beta_{\mathrm{k}} \mathrm{x}_{\mathrm{ik}}+\varepsilon_{\mathrm{i}}\right.}{\widehat{\mathrm{Y}}_{\mathrm{i}}} \\
& \frac{Y_{i}}{\widehat{\mathrm{Y}}_{\mathrm{i}}}=\frac{\beta_{0}}{\widehat{\widehat{Y}}_{\mathrm{i}}}+\beta_{1} \frac{X_{i 1}}{\widehat{\mathrm{Y}}_{\mathrm{i}}}+\beta_{2} \frac{X_{i 2}}{\widehat{\widehat{Y}}_{\mathrm{i}}}+\cdots+\beta_{k} \frac{X_{i k}}{\widehat{\mathrm{Y}}_{\mathrm{i}}}+u_{i}
\end{aligned}
$$

\subsection{Metode Transformasi Box-Cox}

Transformasi Box Cox adalah transformasi pangkat pada respon. Box Cox mempertimbangkan kelas transformasi berparameter tunggal, yaitu $\lambda$ yang dipangkatkan pada variabel respon $\mathrm{Y}$ sehingga transformasinya menjadi $Y^{\lambda}$ dan $\lambda$ adalah parameter yang perlu diduga [7]. Tabel 1 berikut adalah beberapa nilai $\lambda$ dengan model transformasinya [8]. Menurut Box dan Cox (1964) transformasi Box Cox untuk respon $\mathrm{Y}$ yang bertanda positif $(Y>0)$, dapat dituliskan sebagai berikut.

$$
V_{i}=\left\{\begin{array}{l}
\left(\frac{Y_{i}^{\lambda}-1}{\lambda}\right), \lambda \neq 0 \\
\log \left(Y_{i}\right), \lambda=0
\end{array}\right.
$$

Jika Y negatif $(Y<0)$, maka transformasi dinyatakan sebagai berikut. 


$$
V_{i}=\left\{\begin{array}{l}
\left(\frac{\left(Y_{i}+c\right)^{\lambda}-\lambda}{\lambda}\right), \lambda \neq 0 \\
\log \left(Y_{i}+c\right), \lambda=0
\end{array}\right.
$$

dengan $\mathrm{c}$ adalah nilai sembarang sedemikian sehingga $Y \geq 0$. Persamaan linearnya dapat dituliskan sebagai berikut [9].

$V_{i}=\beta_{0}+\beta_{1} x_{i 1}+\beta_{2} x_{i 2}+\cdots+\beta_{k} x_{i k}+\varepsilon_{i}$

Tabel 1. Tabel nilai $\lambda$ dan model transformasinya

\begin{tabular}{cc}
\hline$\lambda$ & Transformasi \\
\hline 2 & $Y^{2}=Y^{2}$ \\
\hline 1 & $Y^{1}=Y$ \\
\hline 0.5 & $Y^{0.5}=\sqrt{Y}$ \\
\hline 0 & $Y^{0}=\ln Y$ \\
\hline-0.5 & $Y^{-0.5}=\frac{1}{\sqrt{Y}}$ \\
\hline-1 & $Y^{-1}=\frac{1}{Y}$ \\
\hline-2 & $Y^{-2}=\frac{1}{Y^{2}}$
\end{tabular}

Sumber : Kutner, 2005

Parameter $\lambda$ pada persamaan (11) dengan menggunakan metode kemungkinan maksimum. Berikut persamaanya.

$$
L(\lambda)=\frac{1}{2 \pi^{\frac{n}{2}} \sigma^{n}} e^{-\frac{1}{2 \sigma^{2}} \sum_{i=1}^{n}\left(V_{i}-\beta_{0}-\beta_{1} x_{i 1}-\beta_{2} x_{i 2}-\cdots-\beta_{k} x_{i k}\right)^{2}} \cdot J(\lambda, Y)
$$

dengan

$$
J(\lambda, Y)=\prod_{1}^{n} \frac{d V}{d Y}=\prod_{1}^{n} Y_{i}^{\lambda-1}
$$

Didapatkan persamaan untuk nilai $\lambda$ yang telah ditetapkan sebagai berikut.

$$
L_{\max }(\lambda)=-\frac{n}{2} \ln \hat{\sigma}^{2}(\lambda)+(\lambda-1) \sum_{i=1}^{n} \ln Y_{i}
$$

dengan :

$$
\begin{array}{ll}
n & =\text { Banyak amatan } \\
\hat{\sigma}^{2}(\lambda) & =\frac{1}{n} \sum_{i=1}^{n}(V-\hat{V})^{2}
\end{array}
$$

Memaksimalkan nilai $\lambda$ yang ditetapkan adalah sama dengan meminimalkan $\hat{\sigma}^{2}$ dan meminimalkan Jumlah kuadrat eror [10]

\section{Hasil dan Diskusi}

Langkah pertama dalam penelitian ini yakni mengklusterkan variabel respon $\mathrm{Y}$ yakni pendapatan yang kemudian dimasukkan sebagai variabel prediktor sehingga 
didapatkan bentuk persamaan regresi dengan tambahan variabel dummy sebagai berikut.

$$
Y_{i}=\beta_{0}+\beta_{1} x_{1}+\beta_{2} x_{2}+\beta_{3} D_{1}+\varepsilon_{i}
$$

Berdasarkan Persamaan 13 dilakukan pengestimasian dengan metode kuadrat terkecil terboboti dan metode transformasi Box-Cox.

\subsection{Metode Kuadrat Terkecil Terboboti}

Metode kuadrat terkecil terboboti merupakan metode estimasi parameter dengan menggunakan pembobot. Dalam penentuan pembobotnya dapat dilakukan dengan melihat pola grafik dari sisaan (residual) terhadap variabel prediktor, berikut plot grafiknya.
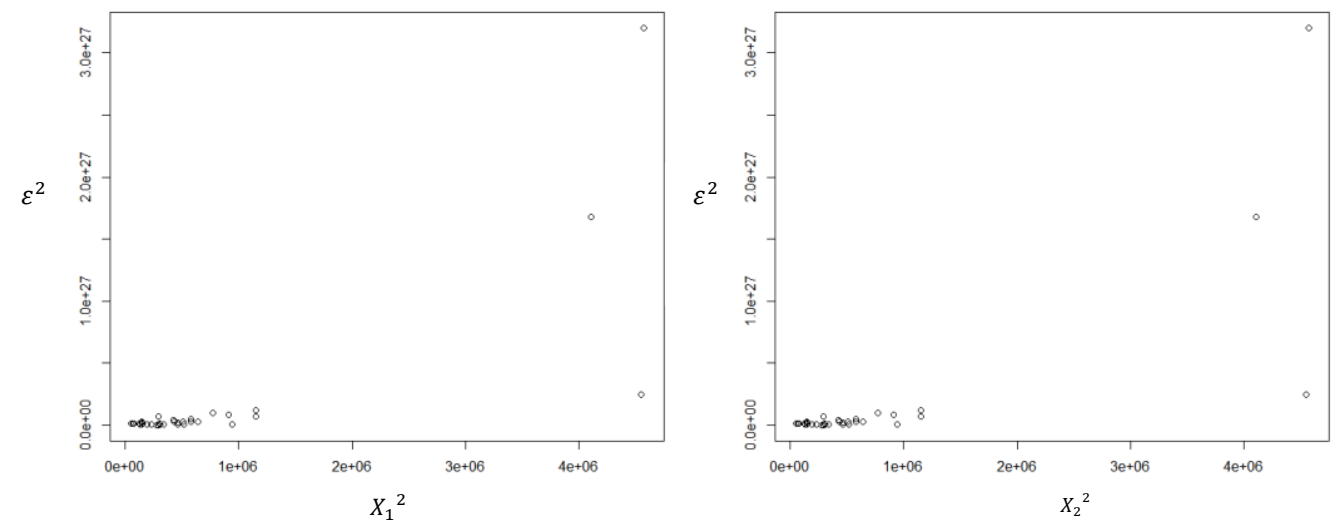

Gambar 4. pola grafik dari sisaan (residual) terhadap variabel prediktor

Berdasarkan dari hasil pola grafik diatas terlihat menunjukkan pola hubungan kuadrat seperti pada Gambar 1 maka dapat diasumsikan variansi eror proporsional terhadap $X_{i j}{ }^{2}$,maka pembobot yang digunakan dalam metode kuadrat terkecil terboboti adalah $\frac{1}{X_{i j}}$ sehingga persamaan regresinya menjadi.

$$
\frac{Y_{i}}{X_{i j}}=\frac{\beta_{0}}{X_{i j}}+\beta_{1} \frac{X_{i 1}}{X_{i j}}+\beta_{2} \frac{X_{i 2}}{X_{i j}}+\cdots+\beta_{k} \frac{X_{i k}}{X_{i j}}+v
$$

Berikut hasil estimasi untuk parameter dengan metode kuadrat terkecil terboboti dengan pembobot $\frac{1}{X_{1}}$.

$$
Y=1.12 \times 10^{13}-2.3 \times 10^{7} x_{1}+1.47 x_{2}-1.09 \times 10^{13} D_{1}
$$

Berikut hasil estimasi untuk parameter dengan metode kuadrat terkecil terboboti dengan pembobot $\frac{1}{X_{2}}$.

$$
Y=91.5 \times 10^{13}-1.68 \times 10^{7} x_{1}+1.43 x_{2}-87.2 \times 10^{13} D_{1}
$$


Berdasarkan hasil estimasi dengan pembobot $\frac{1}{X_{1}}$ dan $\frac{1}{X_{2}}$, didapatkan hasil $R^{2}$ dan RMSE. Dari Tabel 2 didapatkan nilai $R^{2}$ untuk pembobot $\frac{1}{X_{1}}$ sedikit lebih besar dibandingkan pembobot $\frac{1}{X_{2}}$, dengan nilai $98 \%$ yang berarti variabel prediktor yakni banyak usaha dan pengeluaran dapat menjelaskan variabel respon yakni pendapatan sebesar $98 \%$. Nilai RMSE dari pembobot $\frac{1}{X_{1}}$ dant $\frac{1}{X_{2}}$ memiliki selisih yang cukup dekat sehingga dapat dikatakan kedua pembobot signifikan untuk digunakan dalam mengatasi heteroskedastisitas. Selain itu terjadi peningkatan nilai RMSE dan $R^{2}$ tanpa dummy dan dengan dummy, pada tabel 2 dapat terlihat terjadi kenaikan nilai $R^{2}$ dan penurunan nilai RMSE dari kedua pembobot. Sehingga dapat dikatakan dengan adanya tambahan variabel dummy ini dapat memperbaiki model regresi berganda.

Tabel 2. Perbandingan nilai RMSE dan $R^{2}$ dari pembobot $\frac{1}{X_{1}}$ dan $\frac{1}{X_{2}}$, dengan dan tanpa dummy

\begin{tabular}{ccccc}
\hline \multirow{2}{*}{ Pembobot } & \multicolumn{2}{c}{ Tanpa dummy } & \multicolumn{2}{c}{ Dengan dummy } \\
\cline { 2 - 5 } & $R^{2}$ & RMSE & $R^{2}$ & RMSE \\
\hline$\frac{1}{X_{1}}$ & $95 \%$ & $14.1 \times 10^{12}$ & $98 \%$ & $13.6 \times 10^{12}$ \\
\hline$\frac{1}{X_{2}}$ & $95 \%$ & $14.1 \times 10^{12}$ & $97 \%$ & $13.8 \times 10^{12}$ \\
\hline
\end{tabular}

Sumber : Data diolah 2020

Hasil uji asumsi homoskedastisitas berdasarkan metode grafik didapatkan pola grafik tersebar secara acak dan tidak memiliki pola tertentu sehingga dapat dikatakan asumsi homoskedastisitas telah terpenuhi.
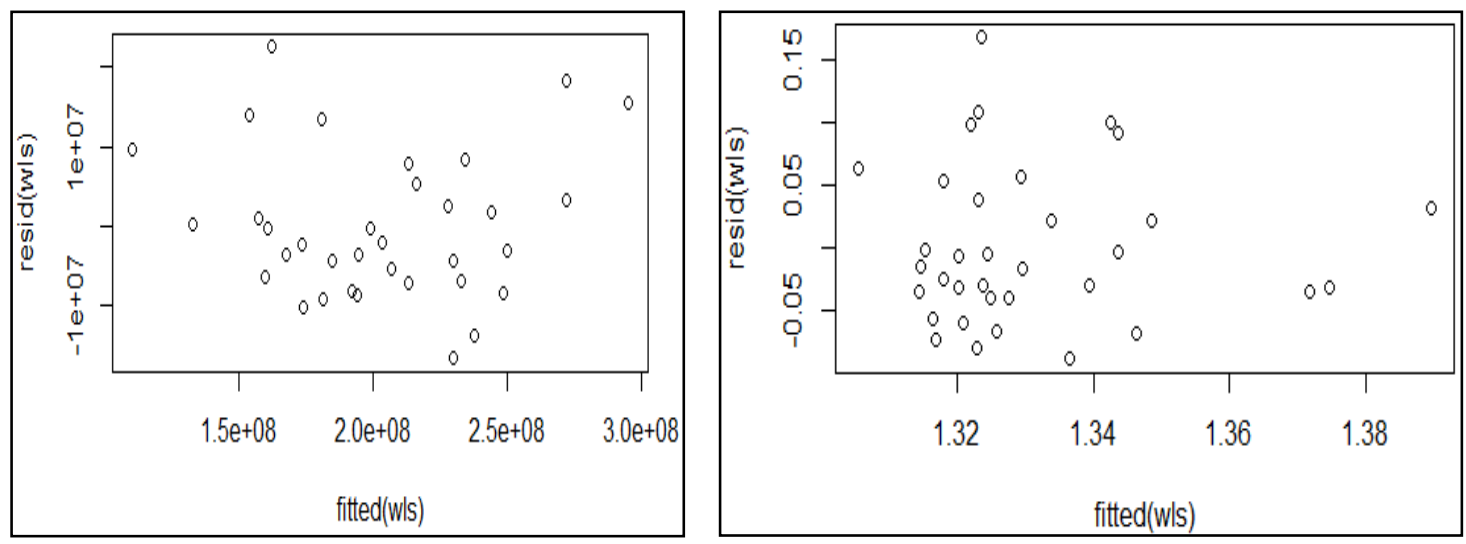

Gambar 5. Uji asumsi homoskedastisitas dengan grafik untuk pembobot $\frac{1}{X_{1}}$ dan $\frac{1}{X_{2}}$ 


\subsection{Metode transformasi Box-Cox}

Estimasi parameter dengan metode transformasi Box-Cox langkah pertama dilakukan pemilihan lamda, umumnya digunakan kisaran lamda $(-2,2)$ dan dapat diperlebar sesuai kebutuhan. Berikut hasil perhitungan Lmaks dari lamda kisaran (-2,2).

Tabel 3. Hasil perhitungan Lmaks

\begin{tabular}{cc}
\hline Lambda & Lmaks \\
\hline-2 & $-2357,36$ \\
\hline-1 & $-1556,42$ \\
\hline$-0,5$ & $-1537,655$ \\
\hline 0 & $-1596,82$ \\
\hline $\mathbf{0 , 5}$ & $\mathbf{- 1 0 2 5 , 8 2}$ \\
\hline 1 & $-1599,33$ \\
\hline 2 & $-1654,198$ \\
\hline
\end{tabular}

Sumber : Data diolah 2020

Berdasarkan tabel 3 didapatkan lamda dengan Lmaks terbesar yakni lambda $=0,5$, maka transformasi yang digunakan adalah $Y^{0,5}$, sehingga didapatkan $\mathrm{Y}$ baru yang kemudian diregresikan dengan variabel prediktornya. Berikut hasil estimasi dari regresi transformasi Box-Cox.

$$
Y=-1.59 \times 10^{7}+6.15 x_{1}+2.82 \times 10^{-8} x_{2}+2.02 \times 10^{7} D_{1}
$$

Hasil uji asumsi homoskedastisitas berdasarkan metode grafik didapatkan pola grafik tersebar secara acak dan tidak memiliki pola tertentu sehingga dapat dikatakan asumsi homoskedastisitas telah terpenuhi.

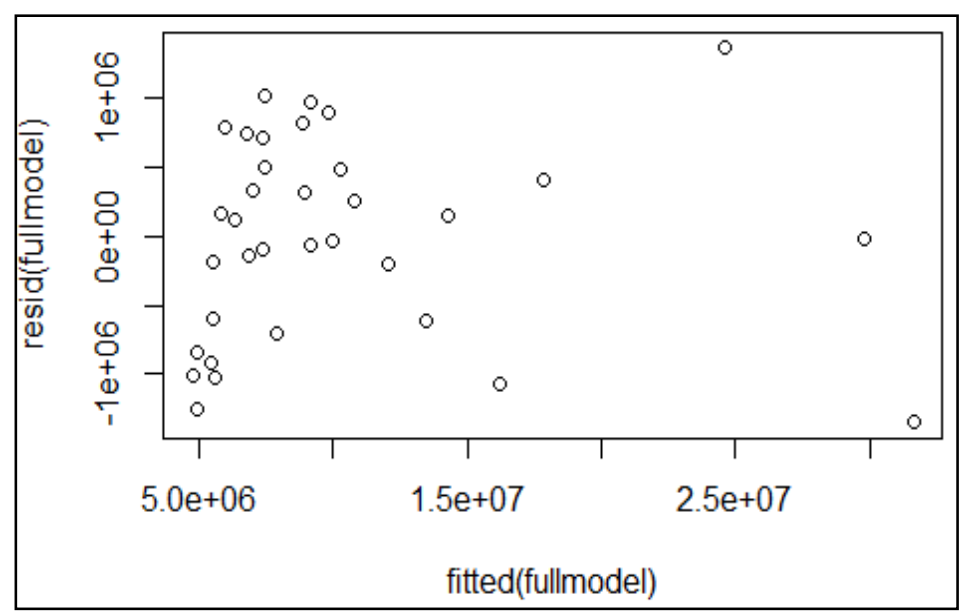

Gambar 6. Uji asumsi homoskedastisitas dengan grafik 


\subsection{Uji Kelayakan model}

Uji kelayakan model dilakukan untuk mengetahui metode yang terbaik digunakan dalam mengatasi heteroskedastisitas. Dengan melihat perbandingan nilai RMSE dan $R^{2}$ dari metode kuadrat terkecil dan metode transformasi Box-Cox. Berikut hasil perbandingannya.

Tabel 4. Perbandingan nilai RMSE dan $\boldsymbol{R}^{\mathbf{2}}$ dari metode kuadrat terkecil terboboti dan transformasi Box-Cox tanpa variabel dummy dan dengan variabel dummy

\begin{tabular}{lcccc}
\hline \multirow{2}{*}{ Metode Estimasi } & \multicolumn{2}{c}{ Tanpa dummy } & \multicolumn{2}{c}{ Dengan dummy } \\
\cline { 2 - 5 } & RMSE & $R^{2}$ & RMSE & $R^{2}$ \\
\hline Kuadrat Terkecil Terboboti & $14.1 \times 10^{12}$ & $95 \%$ & $13.6 \times 10^{12}$ & $98 \%$ \\
\hline Transformasi Box-Cox & $47.4 \times 10^{12}$ & $84 \%$ & $21.6 \times 10^{12}$ & $96 \%$ \\
\hline
\end{tabular}

Sumber : Data diolah 2020

\section{Kesimpulan}

Berdasarkan hasil analisis data dan pembahasan pada penelitian ini dapat ditarik kesimpulan estimasi parameter dengan metode kuadrat terkecil terboboti dilakukan dengan memilih pembobot terlebih dahulu. Dalam penelitian ini digunakan pembobot $\frac{1}{X_{i j}}$ dengan persamaan sebagai berikut:

$$
\frac{Y_{i}}{X_{i j}}=\frac{\beta_{0}}{X_{i j}}+\beta_{1} \frac{X_{i 1}}{X_{i j}}+\beta_{2} \frac{X_{i 2}}{X_{i j}}+\cdots+\beta_{k} \frac{X_{i k}}{X_{i j}}+\frac{\varepsilon_{i}}{X_{i j}}
$$

Berdasarkan dari model yang diperoleh dapat diketahui banyak usaha $\left(X_{1}\right)$, Pengeluaran $\left(X_{2}\right)$ dan variabel dummy secara bersama-sama berpengaruh secara signifikan terhadap Pendapatan $(Y)$ dengan nilai RMSE yang didapatkan sebesar $13.6 \times 10^{14}$ dengan nilai $\mathrm{R}^{2}$ yakni $98 \%$ yang berarti variabel banyak usaha $\left(X_{1}\right)$, Pengeluaran $\left(X_{2}\right)$ dan variabel dummy $\left(D_{1}\right)$ mempengaruhi Pendapatan $(\mathrm{Y})$ sebesar $98 \%$ sisanya dijelaskan oleh variabel lain.

Estimasi parameter dengan metode transformasi Box-Cox dilakukan dengan mencari nilai lamda berdasarkan perhitungan nilai Lmaks terbesar. Dalam penelitian ini digunakan $\lambda=0,5$ maka $Y$ ditransformasi menjadi $Y^{0,5}$ berikut bentuk persamaannya;

$$
Y_{i}^{0.5}=\beta_{0}+\beta_{1} x_{i 1}+\beta_{2} x_{i 2}+\cdots+\beta_{j} x_{i j}+\cdots+\beta_{k} x_{i k}+\varepsilon_{i}
$$

Berdasarkan dari model yang diperoleh dapat diketahui banyak usaha ( $X_{1}$, Pengeluaran $\left(X_{2}\right)$ dan variabel dummy $\left(D_{1}\right)$ secara bersama-sama berpengaruh secara signifikan terhadap Pendapatan (Y) dengan nilai RMSE yang didapatkan sebesar $21.6 \times$ $10^{12}$ dengan nilai $\mathrm{R}^{2}$ yakni $96 \%$ yang berarti variabel banyak usaha $\left(X_{1}\right)$, Pengeluaran $\left(X_{2}\right)$ dan variabel dummy mempengaruhi Pendapatan (Y) sebesar 96\% sisanya dijelaskan oleh variabel lain. 
Dari hasil estimasi kedua metode didapatkan model estimasi dengan metode kuadrat terkecil terboboti merupakan metode terbaik digunakan dalam mengatasi heteroskedastisitas pada data banyaknya usaha/perusahaan, pendapatan, dan pengeluaran usaha mikro kecil menurut wilayah di Indonesia tahun 2016 dengan nilai root mean square error yakni $13.6 \times 10^{14}$ dan $\mathrm{R}^{2}$ adalah $98 \%$.

\section{Daftar Pustaka}

[1] Gujarati, D.N. Basic Econometric. $4^{\text {th }}$ ed. New York : The McGraw-Hill Companies, 2004.

[2] Asmoro, Y.W. Pendeteksian dan Perbaikan Heteroskedastisitas dalam Regresi Linier Menggunakan Metode Weighted Least Squares (WLS) dan Transformasi Variabel. Skripsi. Universitas Sanata Dharma, 2013.

[3] Setyaningsih, Y.D. Penggunaan Metode Weighted Least Square Untuk Mengatasi Masalah Heteroskedastisitas Dalam Analisis Regresi (Studi Kasus Pada Data Balita Gizi Buruk Tahun 2014 di Provinsi Jawa Tengah). Jurnal Statistika Industri dan Komputasi, Volume 2, No. 1, pp. 51-58, 2017.

[4] Hanifah, N., Herhyanto, N. \& Agustina, F. Penerapan Metode Weighted Least Square untuk mengatasi Heteroskedastisitas pada Analisis Regresi Linear. Eurekamatika, Vol 3, No.1, 2015.

[5] Cahyani, N.W.Y., Srinadi, I.G.A.M. \& Susilawati, M. Perbandingan Transformasi Box-Cox dan Regresi Kuantil Median dalam Mengatasai Heteroskedastisitas. EJurnal Matematika, Vol. 4(1), januari 2015, pp. 8-13, 2015.

[6] Maziyya, P.A, Sukarsa, I.K.G. \& Asih, N.I. Perbandingan Transformasi Box-Cox dan Regresi Kuantil Median dalam Mengatasi Heteroskedastisitas. E-Jurnal Matematika, Vol. 4 (1), pp. 8-13, 2015.

[7] Fransiska, W., Nugroho, S. \& Faisal,F. Transformasi Box Cox dalam Analisis Regresi Linier Sederhana. E-jurnal FMIPA Universitas Bengkulu, 2012.

[8] Kutner, M.H, Nachtsheim, C.J, Neter, J. \& Li, W. Applied Linear Statistical Models. Fifth ed. New York: The McGraw-Hill Companies, 2005.

[9] Box, G. E. P. \& Cox, D. R.An Analysis of Transformations. Journal of the Royal Statistical Society. Series B (Methodological), Vol. 26, No. 2, pp.211-252, 1964.

[10] Ispriyanti, D. Pemodelan Statistika dengan Transformasi Box - Cox. Jurnal Matematika dan Komputer, Volume 7, pp. 8-17, 2004. 